\title{
ОСОБЕННОСТИ РАЗВИТИЯ ВИРУСА ОБЫКНОВЕННОЙ МОЗАИКИ ФАСОЛИ (Potyvirus, Potyviridae) В УСЛОВИЯХ МОСКОВСКОГО РЕГИОНА И ИСХОДНЫЙ МАТЕРИАЛ ДЛЯ СЕЛЕКЦИИ НА УСТОЙЧИВОСТЬ
}

\author{
И.А. ЕНГАЛЫЧЕВА $~$, Е.Г. КОЗАРЬ, А.С. ДОМБЛИДЕС, А.А. АНТОШКИН, \\ В.Ф. ПИВОВАРОВ, А.А. УШАКОВ, В.А. УШАКОВ
}

Вирус обыкновенной мозаики фасоли (Bean common mosaic virus, BCMV) в последние годы значительно расширяет ареал распространения и становится важным в экономическом отношении возбудителем болезни на фасоли овощной (Phaseolus vulgaris L.) в Нечерноземной зоне России. Начиная с 2014 года, отмечено возникновение эпифитотий в Московском регионе, однако целенаправленный скрининг отечественных и зарубежных сортов культуры на устойчивость к BCMV здесь не проводился. В представленной работе впервые описаны особенности развития BCMV в условиях Московской области, установлено сочетание климатических факторов, определяющих степень развития болезни, а также дана оценка обширного сортимента сортов фасоли овощной по признаку устойчивости к BCMV с использованием молекулярных маркеров. Целью наших исследований стал поиск источников устойчивости к вирусу обыкновенной мозаики фасоли (BCMV) различного происхождения для включения в селекционный процесс по созданию новых отечественных сортов фасоли спаржевого типа с требуемым сочетанием признаков. Мониторинг развития ВCMV на посевах фасоли овощной в агроценозе Московской области проводили в 2014-2019 годах на базе ФГБНУ Федеральный научный центр овощеводства. Материалом служили 207 коллекционных образцов (45-60 растений каждого сорта) различного географического и генетического происхождения. Изолят ВCMV был выделен из пораженных растений этой культуры. Биотестирование осуществляли посредством искусственного заражения гороха сорта Жегаловец и фасоли сорта Грибовская 92. В работе использовали методы визуальной и серологической диагностики, биотестирования, фитопатологический мониторинг развития болезни. Полевую оценку устойчивости образцов проводили в динамике по 4-балльной шкале, ранжирование по группам устойчивости - на основе показателя степени развития болезни с учетом стабильности проявления признака в разные годы. ДНК-маркирование основных генов устойчивости (доминантного гена $I$, рецессивных генов $b c-1^{2}$ и $\left.b c-3\right)$ осуществляли с помощью соответствующих маркеров SW13, SBD5 и ROC11 согласно разработанным протоколам. В результате исследований были выявлены биологические особенности московского изолята ВCMV, который in vitro поражает виды Phaseolus vulgaris L. и Pisum sativum L. семейства Fabaceae. На характер проявления симптомов и интенсивность поражения растений-индикаторов при биотестировании и образцов фасоли в полевых условиях существенное влияние оказывал температурный фактор, а на степень распространения вируса - количество выпавших осадков. Пониженное количество осадков во все периоды вегетации в сочетании с повышенными температурами в целом служили сдерживающим фактором распространения патогена в климатических условиях Московской области. В то же время это сочетание факторов способствовало более интенсивному проявлению визуальных симптомов поражения вирусом листового аппарата растений, особенно в первый период вегетации. Среди 207 изученных образцов только 6 \% проявили стабильно высокую устойчивость к BCMV на фоне эпифитотий. Скрининг 30 образцов с различной устойчивостью показал, что рецессивные гены $b c-1^{2}$ и $b c-3$ присутствуют у болышинства из них, а доминантный ген $I$ - только у половины. Наиболышее число образцов имели генотипы $I / b c-1^{2} / b c-3(33 \%)$ и $-/ b c-1^{2} / b c-3(47 \%)$, из которых стабильно высокую устойчивость к вирусу проявили только $1 / 3$ образцов. При отсутствии генов $I$ и $b c-1^{2}$ было отмечено сильное поражение растений вирусом. Анализ соответствия по критерию $\chi^{2}$ выявил более значимое влияние гена $b c-1^{2}$ на степень полевой устойчивости образцов к BCMV. По совокупности всех полученных результатов в качестве исходного материала для создания сортов фасоли овощной спаржевого типа с высокой устойчивостью к BCMV рекомендованы 17 наиболее перспективных коллекционных образцов различного происхождения, пять сортов (Хавская универсальная, Рант, Золушка, Мариинка, Светлячок) и два перспективных сортообразца (СП-232, КП-84) селекции ФГБНУ ФНЦО с комплексом других хозяйственно ценных признаков.

Ключевые слова: Phaseolus vulgaris L., фасоль овощная, вирус обыкновенной мозаики фасоли, ВСMV, вирусоустойчивость, гены устойчивости, стабильность устойчивости, ДНК маркеры, исходный материал, селекция.

Фасоль обыкновенная (Phaseolus vulgaris L.) - третья по значимости и занимаемым площадям пищевая зернобобовая культура в мире, которая уступает только сое Glycine max (L.) Merr. и apaхису Arachis hypogea L. 
(1). В последнее время ее рассматривают как функциональный продукт питания с высоким содержанием белков, витаминов, антиоксидантов и микроэлементов, а также с отличными вкусовыми качествам $(1,2)$. По данным ФАО (Food and Agriculture Organization, FAO) за 2018 год, самые обширные посевные площади под фасолью овощной заняты в странах Латинской Америки, Восточной и Южной Африки (3). В последние годы промышленное производство этой важной культуры начинает активно развиваться и в России (4).

Среди патогенных микроорганизмов, поражающих Ph. vulgaris, значительную часть составляют вирусы, в особенности афидофильные. На сегодняшний день известно около десяти видов вирусов, среди которых наиболее вредоносны и повсеместно распространены вирус обыкновенной мозаики фасоли (Bean common mosaic virus, BCMV), вирус желтой мозаики фасоли (Bean yellow mosaic virus, BYMV), вирус некротической мозаики фасоли (Bean common mosaic necrosis virus, BCMNV) из семейства Potyviridae и вирус скручивания листьев фасоли (Bean leafroll virus, BLRV) из семейства Luteoviridae. Остальные виды относят к группе эндемичных, появление которых связано с определенными условиями разных стран и регионов $(1,5,6)$.

BCMV впервые был обнаружен в 1917 году в США (7). В настоящее время он наиболее вредоносен в экономическом отношении: в ряде стран эпифитотии по разным оценкам ежегодно приводят к 50-100 \% потерям урожая бобовых культур (8-13). В Российской Федерации BCMV первые был описан в 1980-х годах на клевере луговом на Дальнем Востоке, а спустя десятилетие и на культуре фасоли в ряде других регионов $(14,15)$.

Для BCMV характерна вертикальная передача через пыльцу и семена: вирус обнаружен в семенной кожуре, семядолях и зародышах $(6,8$, 9). На инфицирование семян значительное влияние оказывает время заражения растения: наиболее уязвимый период - фаза дифференцировки зачатков органов цветка, тогда как при заражении после цветения вероятность семенной передачи BCMV существенно снижается (16). В векторной передаче вируса неперсистентным путем при наличии источника инфекции активно участвует 11 видов тли. Большинство из них в считанные минуты эффективно передают вирус как крылатые мигранты, но также быстро теряют эту способность $(6,9,17)$. Круг естественных резерваторов BCMV в основном ограничен культурными и дикорастущими видами семейства Fabaceae из родов Phaseolus, Pisum, Trifolium, Vicia (11, 18-20).

BCMV в природе существует как комплекс штаммов, которые подразделяют на восемь патогрупп (PG): пять для BCMV (PG-1, PG-2, PG-4, PG-5, PG-7) и три для родственного по серологическим характеристикам вируса некротической мозаики фасоли - BCMNV (PG-3, PG-6, PG-8) (21). Молекулярные исследования последних лет показали, что все перечисленные штаммы характеризуются высоким генетическим разнообразием и множеством идентифицированных рекомбинантов (10, 22-25). Дифференцировку штаммов проводят по характеру проявления симптоматики у сортов фасоли овощной с различными комбинациями семи известных в настоящее время генов устойчивости - одним штамм-неспецифическим основным доминантным геном $I$ и шестью штамм-специфическими рецессивными генами $b c-u, b c-1, b c-1^{2}, b c-2, b c-2^{2}$ и $b c-3$ из четырех независимых локусов $(17,26,27)$.

Создание сортов фасоли овощной с множественными генами устойчивости к BCMV - приоритетное направление для многих селекци- 
онных программ, поскольку такие сорта обладают устойчивостью к разнообразным PG вируса $(17,26)$. В рамках MAS-селекции (marker assistant selection) на пирамидальную устойчивость сортов фасоли к BCMV зарубежные ученые все чаще используют сочетание гена $I$ с $b c-3$, что обеспечивает более широкий спектр неспецифической устойчивости $(9,28-31)$. Аллели рецессивных генов группы $b c-1$ и $b c-2$ предотвращают системное распространение вируса. Их сочетание в геноме растения даже без доминантного гена $I$ может быть эффективно против многих патотипов BCMV. Перенос генов устойчивости в восприимчивые образцы с помощью косвенной селекции под контролем ДНК маркеров предпринимался в отношении локусов $I(32,33), b c-3(31), b c-1^{2}(34,35) b c-1$ и $b c-u(36)$. Для интродуцирования гена устойчивости $I$ в восприимчивые генотипы использовали маркер SW13 (28, 37-39). Кроме того, маркеры SW13 и SBD5 применяли для пирамидирования генов $b c-1^{2}$ и $I$ в восприимчивый генотип (35). Для гена $b c-3$ разработаны маркеры ROC11 и SG6, которые также можно использовать совместно с другими маркерами $(31,40)$. Таким образом, маркер SW13 сцеплен с геном I, маркер SBD5 связан с наличием гена $b c-1^{2}$, маркеры ROC11 и SG6 определяют соответственно присутствие и отсутствие аллеля $b c-3$. При селекции в последние годы используют рецессивный ген $b c-1^{2}$, который обеспечивает устойчивость растений фасоли к наиболее распространенным патотипам BCMV и BCMNV - PG-1, PG-2, PG-3 и PG-5 $(13,34)$. Следует отметить, что молекулярные методы маркирования $R$-генов служат вспомогательными в схеме селекционного процесса. Основой успеха MAS-селекции остается сочетание молекулярных и классических фитопатологических методов оценки устойчивости растений с использованием искусственных и естественных инфекционных фонов.

В России селекционная работа с культурой фасоли была начата в 1920 году на Грибовской овощной селекционной опытной станции (ныне Федеральный научный центр овощеводства, ФГБНУ ФНЦО). За минувший 100-летний период селекционерами центра создано 45 сортов фасоли, или $32 \%$ от общего числа сортов, представленных в Государственном реестре селекционных достижений, допущенных к использованию. Большая часть ранее созданных сортов фасоли - универсального назначения. В последние годы одним из приоритетных направлений селекционной работы стало создание сортов фасоли овощной (green beans) спаржевого типа, отвечающих требованиям рынка, с высокой устойчивостью к болезням.

В результате изменения климата и неконтролируемого перемещения (ввоза) семенного материала без проведения соответствующей фитопатологической экспертизы BCMV продвинулся в более северные регионы Нечерноземной зоны и Западной Сибири РФ (41-45). Первое эпифитотийное развитие болезни в Московской области зарегистрировано в 20142015 годах, в связи с чем в Федеральном научном центре овощеводства было начато целенаправленное изучение особенностей развития BCMV в условиях этого региона с использованием обширной коллекции образцов вида Ph. vulgaris.

В представленной работе впервые описаны особенности развития BCMV в условиях Московской области, установлено сочетание климатических факторов, определяющих степень развития болезни, а также с использованием молекулярных маркеров дана оценка обширного сортимента сортов фасоли овощной по признаку устойчивости к ВCMV. Выявлены и включены в селекционный процесс новые генетические источники устойчивости фасоли к вирусу обыкновенной мозаики. Скрининг коллекцион- 
ного отечественного генофонда фасоли по признаку устойчивости к вирусу с помощью методов молекулярного маркирования проведен впервые в Российской Федерации.

Нашей целью стал поиск источников устойчивости к вирусу обыкновенной мозаики фасоли (BCMV) различного происхождения для включения в селекционный процесс по созданию новых отечественных сортов фасоли спаржевого типа с требуемым сочетанием признаков.

Методика. Мониторинг развития вируса обыкновенной мозаики фасоли на посевах фасоли овощной в агроценозе Московской области проводили в 2014-2019 годах на базе ФГБНУ ФНЦО. Материалом служили 207 коллекционных образцов (45-60 растений каждого сорта) различного географического и генетического происхождения, из которых большая часть была представлена сортами из США, Нидерландов, Германии и Российской Федерации, включая перспективные сорта фасоли овощной селекции ФГБНУ ФНЦО. Изолят вируса Bean common mosaic virus был выделен из пораженных растений этой культуры.

Наличие антигенов вируса в листьях растений определяли методом иммуноферментного анализа (ИФА) по сэндвич-варианту с использованием реагентов фирмы «Agdia, Inc.» (США). Результаты ИФА оценивали на полуавтоматическом ИФА-анализаторе (Stat Fax® 2100, «Awareness Technology, Inc.», США) при $\lambda=480$ нм по коэффициентам экстинкции. Во избежание наличия смешанной инфекции и для контроля за распространением других фитовирусов, в частности вируса огуречной мозаики (Cucumber mosaic virus, CMV) и вируса табачной мозаики (Tobacco mosaic virus, TMV), вызывающих схожие с BCMV симптомы, применяли иммунологический экспресс-метод диагностики заболеваний с использованием иммунострипов («Agdia, Inc.», США).

Биотестирование вируса на горохе (Pisum sativum L.) сорта Жегаловец и фасоли (Phaseolus vulgaris L.) сорта Грибовская 92 для изучения его особенностей проявления и оценку фенотипической устойчивости у 30 перспективных коллекционных образцов фасоли к BCMV проводили посредством искусственного заражения растений в условиях пленочной теплицы. В исследования были включены 10 растений каждого сорта в 3кратной повторности. Растения высевали в два срока: в III декаде апреля, когда среднесуточная температура в теплице составляла 20-22 ${ }^{\circ} \mathrm{C}$, и в I декаде июня при среднесуточной температуре 26-29 ${ }^{\circ} \mathrm{C}$. Инокуляцию осуществляли в фазу примордиальных листьев механически втиранием неочищенного сока из листьев инфицированного растения в 0,1 М фосфатном буфере $(\mathrm{pH} 7,0)$ с карборундом, используя протокол L.J. Mills c coaвт. (46). Наличие или отсутствие вирусной инфекции у тестируемых растений подтверждали методами визуальной и серологической диагностики (ИФА).

Коллекционные образцы фасоли овощной в 2014-2019 годах высевали в поле (Московская обл., Одинцовский р-н) на естественном инфекционном фоне по схеме рандомизированных блоков так, чтобы каждый образец имел приблизительно одинаковые шансы на заражение. Поражение вирусной инфекцией оценивали методом визуальной диагностики характерных симптомов на листьях по модифицированной шкале: 0 отсутствие симптомов, 0,5 - слабое проявление симптомов на единичных листьях, 1 - поражено менее $10 \%, 2$ - поражено 10-30 \%, 3 - поражено 30-50\%, 4 - поражено более $50 \%$ всей листовой поверхности растения. Устойчивость каждого образца определяли по общепринятым 
показателям: распространенность (P, \%), индекс поражения (I, средний балл), степень развития болезни (R, \%). Учет проводили 3 раза за вегетацию в фазы 3-й пары настоящих листьев, цветения и технической спелости бобов. По совокупности всех оценок образцы дифференцировали на устойчивые $(\mathrm{R}=0)$, относительно устойчивые $(0<\mathrm{R} \leq 10 \%)$, слабовосприимчивые $(10<\mathrm{R} \leq 25 \%)$ и восприимчивые $(\mathrm{R}>25 \%)$, а также по группам стабильности проявления признака: I - симптомов поражения нет, II - симптомы проявляются только в годы эпифитотий, III - нестабильное проявление признака в разные годы, IV - стабильное поражение BCMV во все годы исследований.

В течение вегетационного периода оценивали селекционно ценные признаки образцов согласно методическим рекомендациям по селекции и семеноводству овощных бобовых культур $(47,48)$. Перспективные образцы выделяли на основе их селекционной ценности по комплексу всех изученных признаков.

Из суммарно оцененных за годы исследований образцов отобрали 30 наиболее перспективных с разной степенью и стабильностью проявления полевой устойчивости к BCMV и провели скрининг на наличие генов устойчивости $I, b c-12$ и $b c-3$, по результатам которого образцы включили в селекционную программу по созданию сортов фасоли с устойчивостью к вирусной инфекции. Для проведения ПЦР-анализа использовали маркеры SW13, SBD5 и ROC11.

Ткань молодых листочков каждого растения фасоли овощной размалывали в 200 мкл СТАВ-буфера с использованием прибора TissueLyser II («Qiagen», Германия) (частота 26 Гц, 1560 колебаний/мин, продолжительность 1,7 мин) до состояния суспензии. После измельчения к каждому образцу добавляли 15 мкл протеиназы К. Дальнейшую экстракцию ДНК проводили СТАВ-методом с использованием набора реагентов Сорб-ГМОБ («ООО «Синтол», Россия) согласно протоколу производителя. Конечную чистоту и концентрацию тотальной ДНК определяли спектрофотометрически (Smart Spec Plus, «Bio-Rad», США). Полученное соотношение OD $260 / 280=1,6-1,8$ соответствовало чистому раствору ДНК.

В реакционную смесь объемом 25 мкл входили 2,5 мкл 10× ПЦРбуфер, 2,5 мM MgCl2, 0,25 мМ каждого dNTP, по 0,3 мкM каждого из праймеров, 1,5 ед. SynTaq полимеразы («ООО «Синтол», Россия) и 50 нг ДНК. Последовательности праймеров для трех маркеров устойчивости были взяты из работы S. Hegay с соавт. (49): для SW13 прямой праймер 5'-CACAGCGACATTAATTTTCCTTTC-3', обратный - 5' -CACAGCGACAGGAGGAGCTTATTA-3'); для SBD5 прямой праймер 5'-GTGCGGAGAGGCCATCCATTGGTG-3', обратный - 5'-GTGCGGAGAGTTTCAGTGTTGACA-3'); для ROC11 прямой праймер 5'-CCAATTCTCTTTCACTTGTAACC-3', обратный - 5'-GCATGTTCCAGCAAACC-3'. ПЦР осуществляли на приборе C1000 («Bio-Rad», США) по следующей программе: 2-5 мин при $95^{\circ} \mathrm{C}$ (начальная денатурация); 30 с при $95^{\circ} \mathrm{C}$ (денатурация), 30 с при $59{ }^{\circ} \mathrm{C}, 64,6{ }^{\circ} \mathrm{C}$ и $53{ }^{\circ} \mathrm{C}$ (отжиг соответственно для SW13, SBD5 и ROC11), 30 с при $72{ }^{\circ} \mathrm{C}$ (элогация) (35 циклов); 7 мин при $72{ }^{\circ} \mathrm{C}$ (финальная элонгация). Температуру отжига праймеров корректировали так, чтобы получались четкие единичные и воспроизводимые фрагменты.

Продукты амплификации разделяли в 1,7 \% агарозном геле в $0,5 \times$ TВE-буфере с использованием камеры для горизонтального электрофореза Wide Mini-Sub Cell GT («Bio-Rad», США). Полученные гели окрашивали раствором бромистого этидия и фотографировали с помощью системы 
гель-документирования ChemiDoc XRS+ («Bio-Rad», CША) с последующей обработкой изображений в прилагаемой программе ImageLab («BioRad», CША). Размеры амплифицированных фрагментов определяли в сравнении с маркером молекулярных масс GeneRuler100 bp Plus DNA Ladder («Thermo Fisher Scientific, Inc.», США).

Обработку данных осуществляли с использованием программ LightCycler® ${ }^{\circledR} 80$ SW 1.5.1 («Roche Molecular Systems, Inc.», США) и Microsoft Excel 2010. Вычисляли средние значения (M), их стандартные отклонения $( \pm \mathrm{SD})$ и стандартную ошибку средней $( \pm \mathrm{SEM})$, оценивали уровень значимости различий (p), проводили регрессионный, дисперсионный, корреляционный анализ, анализ соответствия по критерию $\chi^{2}(51)$.

Результаты. Происхождение образцов фасоли обыкновенной, использованных в работе, представлено на рисунке 1.

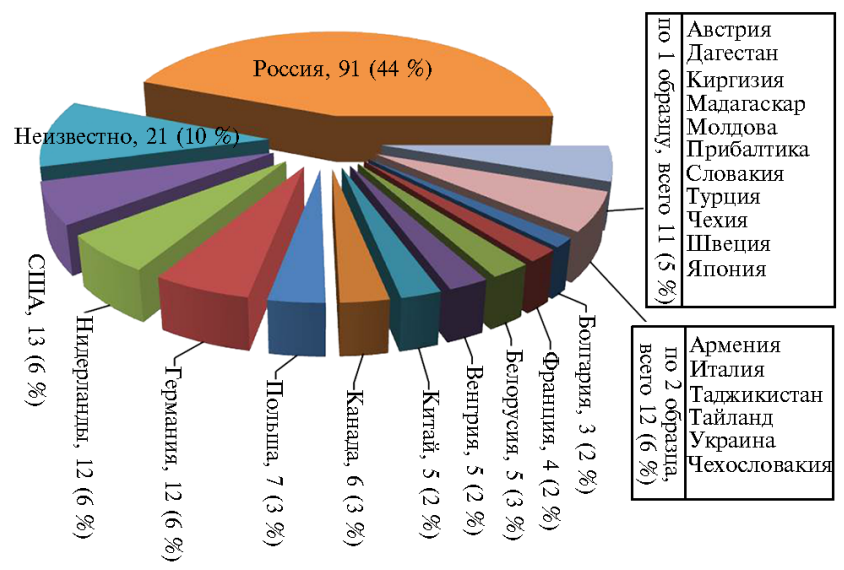

Рис. 1. Происхождение и число образцов фасоли овощной (Phaseolus vulgaris L.) (коллекция ФГБНУ Федерального научного центра овощеводства), использованных при поиске источников устойчивости к вирусу обыкновенной мозаики фасоли (BCMV).

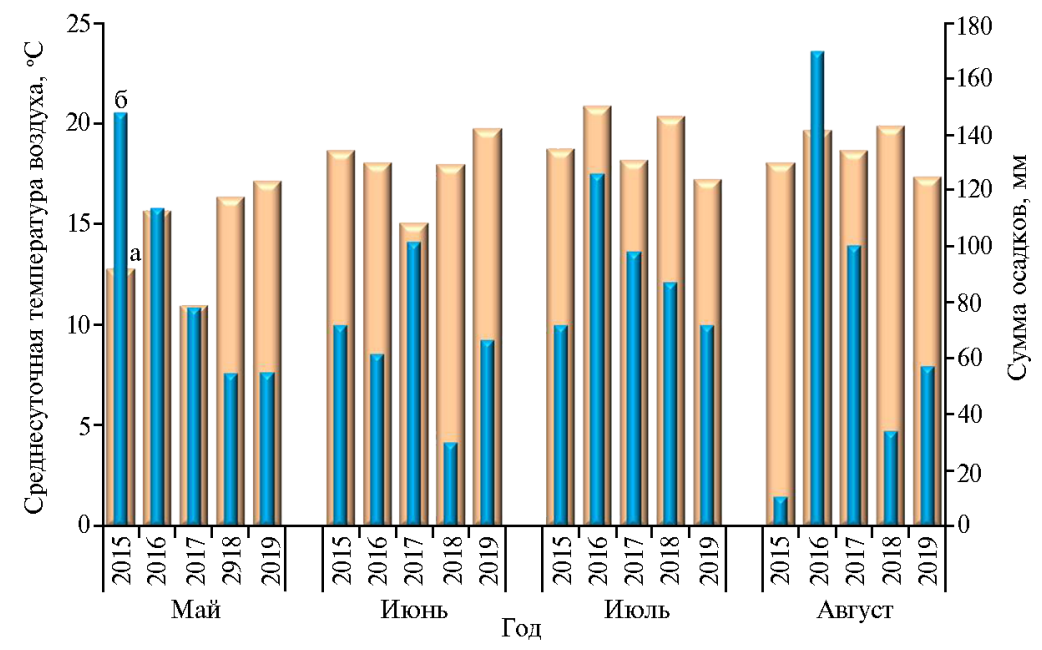

Рис. 2. Среднесуточная температура воздуха (а) и суммарное количество осадков (б) по месяцам при проведении мониторинга развития вируса обыкновенной мозаики фасоли (BCMV) на посевах коллекционных образцов фасоли овощной (Phaseolus vulgaris L.) (Московская обл., Одинцовский р-н).

Погодные условия в годы исследований существенно различались по сочетанию основных климатических факторов в разные периоды вегетации (рис. 2), что повлияло на степень распространения и интенсивность 
поражения BCMV растений фасоли.

В условиях Московской области растения фасоли, инфицированные BCMV, имели типичные симптомы, которые проявлялись как темно-зеленая или светло-зеленая мозаика, часто сопровождающаяся деформацией листовой пластинки в виде морщинистости и скручивания (рис. 3, А). В растениях фасоли с различным баллом поражения BCMV присутствие вируса подтверждали методом ИФА.

Исследования иммунного ответа тест-растений на заражение московским изолятом BCMV показали, что при температуре ниже $26{ }^{\circ} \mathrm{C}$ изолят вызывал слабую мозаику на молодых растениях фасоли BCMV при искусственной инокуляции. В ряде случаев отмечали латентное (бессимптомное) течение болезни в вегетативный период, но при этом вирус активно влиял на развитие репродуктивных органов, снижая продуктивность растений фасоли. При повышенных температурах воздуха (26-29 $\left.{ }^{\circ} \mathrm{C}\right)$ на восприимчивых взрослых растениях фасоли сорта Грибовская 92 появлялись типичные для BCMV симптомы (темно-зеленая мозаика, скрученность или морщинистость листовой пластинки) с последующей некротизацией (см. рис. 3, Б, В). У гороха овощного сорта Жегаловец на ранних этапах развития симптомы отсутствовали, но по мере накопления вирусных частиц ближе к моменту цветения проявилась мозаика с последующей некротизацией (см. рис. 3, Г, Д).
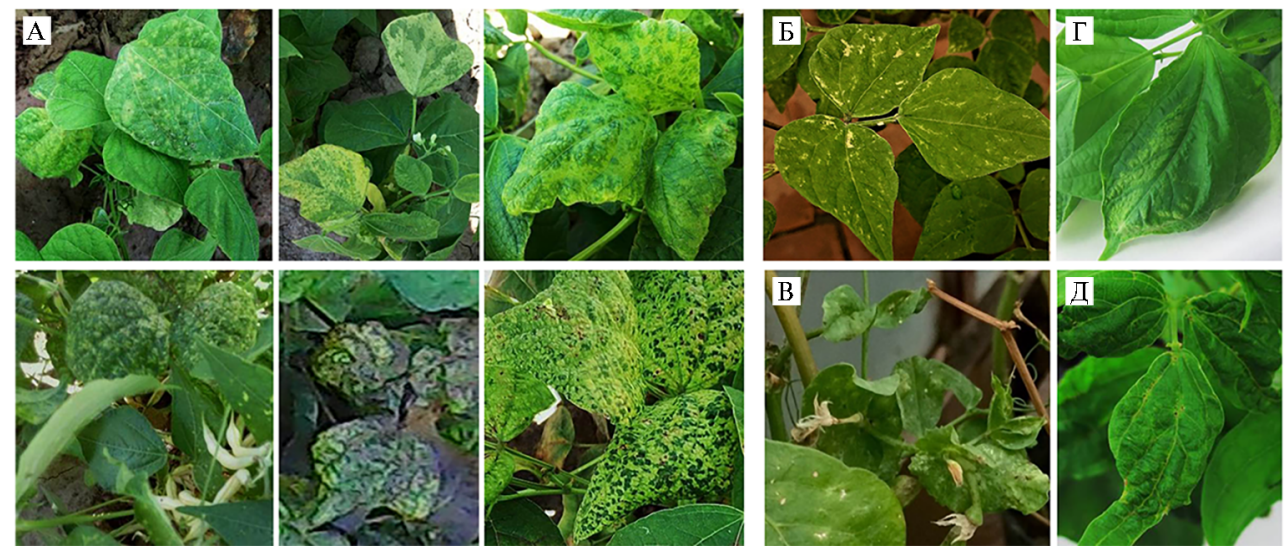

Рис. 3. Примеры проявления симптомов поражения вирусом обыкновенной мозаики фасоли (BCMV) у образцов фасоли овощной (Phaseolus vulgaris L.) (коллекция ФГБНУ Федерального научного центра овощеводства) в открытом грунте (А) (Московская обл., 2014-2019 годы) и у растений фасоли сорта Грибовская 92 (Б, В) и гороха (Pisum sativum L.) сорта Жегаловец при искусственной инокуляции (Г, Д) в условиях теплицы (2015-2016 годы).

Ежегодный фитомониторинг распространения болезней на культуре фасоли овощной на семеноводческих посевах выявил существенное нарастание распространенности BCMV в условиях Московской области, начиная с 2014 года. В 2015, 2016 и 2019 годах наблюдалось эпифитотийное развитие болезни. Максимальное количество пораженных образцов (90\% от общего числа) отмечали в 2016 году, в 2015 и 2019 годах их доля составила около 50 \%. Распространенность болезни в эти годы превысила порог вредоносности, составив в среднем более $30 \%$ растений с симптомами поражения на всей площади посевов (2015 год - 34 \%, 2016 год $81 \%, 2019$ год - 36 \%), при этом наибольший средний индекс поражения (2,7 балла) был зарегистрирован в 2019 году.

В 2017 и 2018 годах отмечали резкое снижение развития болезни. Ее распространенность не превышала $10 \%$. Число пораженных образцов 
составило соответственно 22 и $13 \%$, однако напряженность инфекционного фона в 2018 году была выше и индекс поражения в среднем составил 2,2 балла, а в 2017 - менее 1,0 балла (табл. 1).

Известно, что характер развития любой болезни в конкретной зоне возделывания определяется устойчивостью набора изучаемых образцов и условиями выращивания. Поскольку в течение 5 лет мы вели исследования с постоянным набором коллекционных образцов, это позволило выявить более существенную роль погодных условий года в распространении вируса и степени поражения образцов BCMV в Московской области. Как показал двухфакторный дисперсионный анализ, доля влияния (DV) климатического фактора на общую изменчивость совокупного показателя развития болезни (R) составила $41 \%$, а генетического фактора $-17 \%$. Причем погодные условия года в большей степени определяли распространенность вируса на посевах фасоли овощной (DV = $73 \%)$, чем интенсивность проявления симптомов на пораженных растениях (DV= 50 \%).

1. Характер поражения образцов фасоли овощной (Phaseolus vulgaris L.) (коллекция ФГБНУ Федерального научного центра овощеводства) вирусом обыкновенной мозаики фасоли (BCMV) и распределение образцов по степени устойчивости признака в зависимости от условий года (Московская обл., Одинцовский р-н)

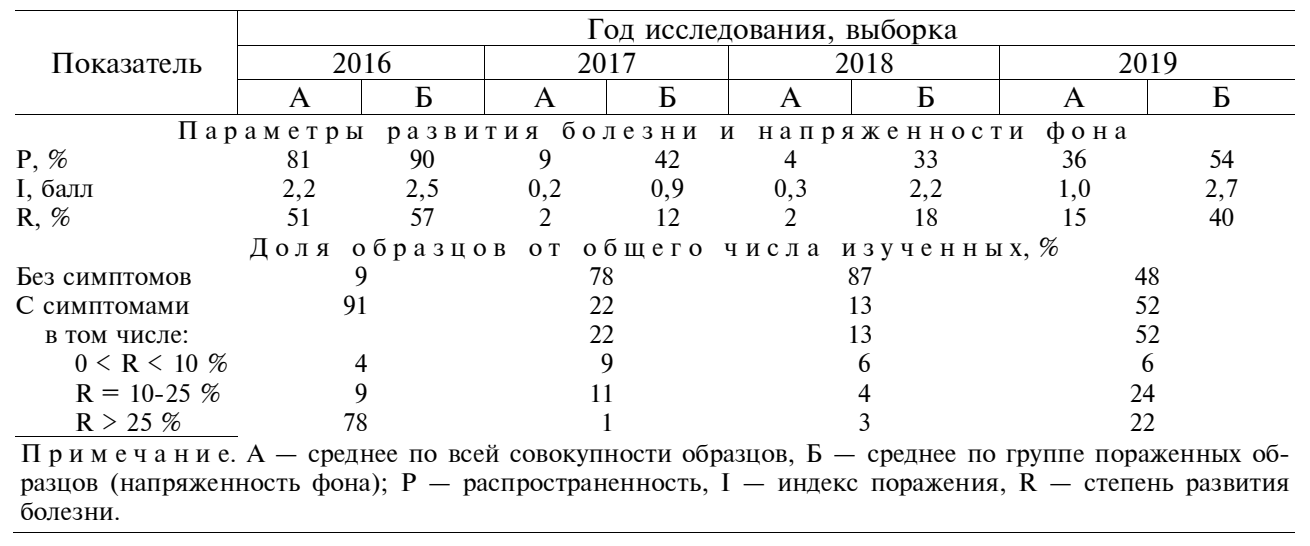

Анализ влияния отдельных климатических факторов в разные периоды вегетации позволил выделить благоприятные и неблагоприятные сочетания условий для развития болезни. Зависимости между средними значениями распространенности и индекса поражения BCMV, с одной стороны, и среднесуточной температурой воздуха $\left(\mathrm{T},{ }^{\circ} \mathrm{C}\right)$ и количеством выпавших осадков $\left(\sum \mathrm{oc}\right)-\mathrm{c}$ другой за каждый месяц вегетации имели сложный характер и описывались полиноминальными кривыми второго и третьего порядков (рис. 4). Тем не менее можно было выделить ряд закономерностей. Интенсивному распространению вируса на посевах фасоли способствовало среднее количество выпавших осадков и средние значения температуры в первую половину вегетации (май $-\sum \mathrm{oc} \sim 110$ мм, Т $\sim 15-16^{\circ} \mathrm{C}$, июнь $-\sum$ ос $\sim 70 \mathrm{Mм}, \mathrm{T} \sim 18^{\circ} \mathrm{C}$ ) и обильные осадки на фоне повышения среднесуточной температуры воздуха во второй половине вегетации ( $\sum$ oc $>120$ мм, $\left.\mathrm{T}>20^{\circ} \mathrm{C}\right)$. Пониженное количество осадков во все периоды вегетации в сочетании с повышенными температурами (май $-\sum$ ос $<60$ мм, Т $>16^{\circ} \mathrm{C}$; июнь $-\sum_{\mathrm{oc}}<70 \mathrm{мм}, \mathrm{T}>18^{\circ} \mathrm{C}$; июль $-\sum \mathrm{oc}<85 \mathrm{Mм}, \mathrm{T}>20^{\circ} \mathrm{C}$; июль $\sum$ oc $<60$ мм и T $\left.>19^{\circ} \mathrm{C}\right)$ в целом служили сдерживающим фактором распространения патогена в климатических условиях Московской области. В то же время это сочетание факторов способствовало более интенсивному 
проявлению визуальных симптомов поражения вирусом листового аппарата растений, особенно в первый период вегетации (см. рис. 4). Так, высокий балл поражения BCMV отмечали в годы с повышенной среднесуточной температурой воздуха $16-18{ }^{\circ} \mathrm{C}$ и минимальным количеством выпавших осадков в мае (2018 и 2019 годы) и при повышении температуры до $18-20{ }^{\circ} \mathrm{C}$ на фоне умеренных осадков в июне (2016 и 2019 годы). Во второй половине вегетации сочетание факторов, способствующих развитию симптомов, имело менее однозначный характер. Это была и прохладная ( Т $\sim 17,2{ }^{\circ} \mathrm{C}$ ) и засушливая ( $\sum$ oc 72 мм) погода в июле 2019 года (при среднемноголетних показателях $18,8^{\circ} \mathrm{C}$ и 81,6 мм), и повышенная температура $\left(\mathrm{T}>20^{\circ} \mathrm{C}\right)$ при обильных осадках ( $\sum$ oc $\sim 87-126$ мм) в 2016 и 2018 годах.

Следует также отметить, что сочетание сухой и жаркой погоды в определенные периоды, чаще в середине вегетации, на относительно устойчивых образцах приводило к снижению интенсивности проявления симптомов, что отмечали в 2015, 2017 и 2019 годах. Так, на ранних стадиях развития (начало июня) доля образцов с четкими симптомами поражения BCMV в 2019 году составила 52 \%, в фазу начала плодоношения в середине июля на фоне жаркой и сухой погоды - 36 \%, а к концу вегетации после похолодания - 47 \%. Явление «маскировки» симптомов под действием высоких температур отмечали и другие авторы $(6,22)$. В связи с этим оценку пораженности образцов фасоли следует проводить в динамике, минимум 2 раза (в первой и во второй половине вегетации), и при ранжировании образцов по группам устойчивости к BCMV учитывать максимальные значения распространенности и индекса поражения растений в образце за весь период вегетации.
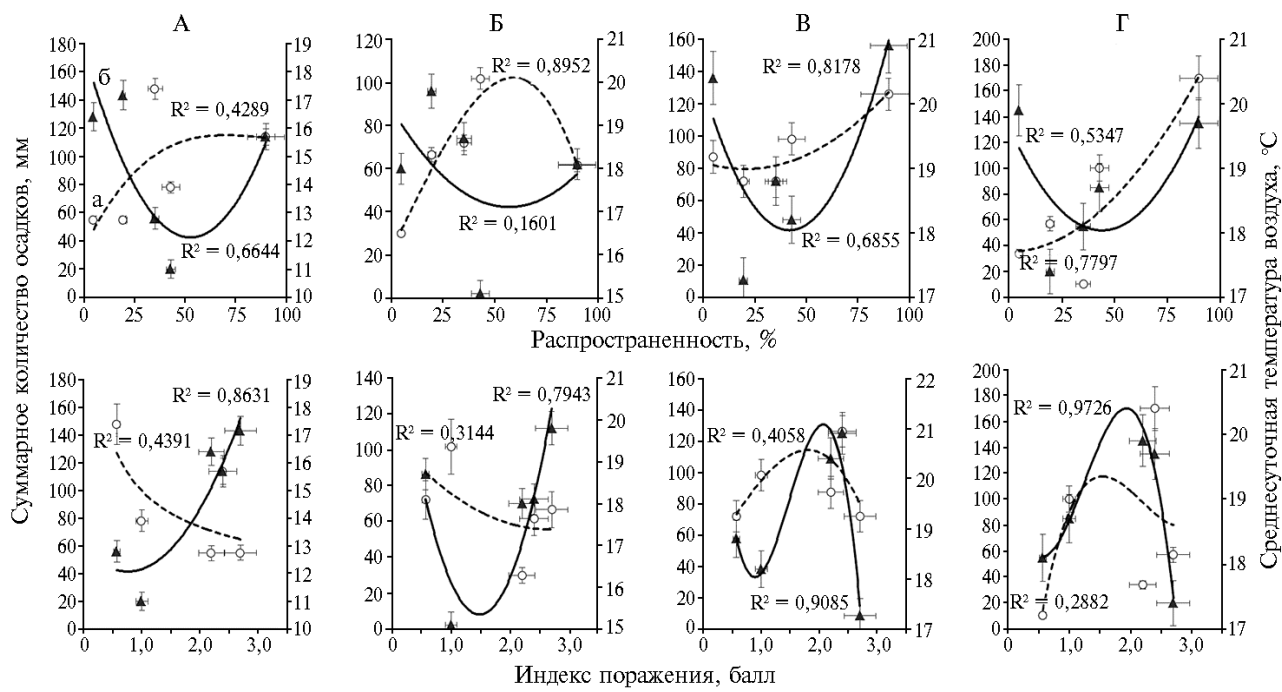

Рис. 4. Характер взаимосвязи между усредненными показателями $(M \pm \mathrm{SD})$ развития вируса обыкновенной мозаики фасоли (BCMV) по всей совокупности образцов фасоли овощной (Phaseolus vulgaris L.) (коллекция ФГБНУ Федерального научного центра овощеводства) в разные годы и параметрами климатических факторов по месяцам вегетации: А - май, Б - июнь, В - июль, Г - август; а, б - полиноминальные кривые зависимости поражения соответственно от среднесуточной температуры воздуха и суммарного количество осадков; кружки и треугольники - соответственно количество осадков (мм) и температура $\left({ }^{\circ} \mathrm{C}\right)$ (Московская обл., Одинцовский р-н, 2015-2019 годы).

При поиске источников устойчивости также важно учитывать стабильность проявления признака устойчивости у каждого образца в годы с разным сочетанием внешних факторов и напряженности естественного 
инфекционного фона. По этому критерию коллекционные образцы распределились на четыре группы стабильности (табл. 2).

B I группу вошли образцы без симптомов поражения растений BCMV во все годы исследований. Доля устойчивых образцов от общего числа составила $6 \%$. Большинство из них были сортами отечественной селекции: Забава (Россия, ВИР к-15356), Изумрудная (Россия, ВИР к15593), Хавская универсальная (Россия), Мулатка (Россия), Фасоль местная овощная (Россия, ВИР к-15673), Золотой нектар (Россия), Западная Сибирь (Россия), Октава (Белоруссия), Рябушка (Россия), Zit 551 RS (Нидерланды, ВИР к-15375), Cade 128 (Нидерланды, ВИР к-15261), Alice Sunshine (США, ВИР к-15599).

B IV группу мы объединили восприимчивые образцы, которые стабильно поражались вирусом независимо от условий года. Их доля составила лишь $2 \%$ от всей совокупности образцов. Это были сорта Киргизская сахарная (Киргизия), Кустовая (Россия), Zatus (Польша) и Грибовская 92 (Россия, ВИР к-12200). Распространенность ВСMV в этой группе образцов в среднем за четыре года исследований была $78 \%$ при среднем индексе поражения 2,5 балла, а в годы эпифитотий распространенность достигала 100 \% при индексе 3-4 балла.

2. Соотношение и характеристика образцов фасоли овощной (Phaseolus vulgaris L.) (коллекция ФГБНУ Федерального научного центра овощеводства) из разных групп стабильности по устойчивости к вирусу обыкновенной мозаики фасоли (BCMV) (Московская обл., Одинцовский р-н, 20152019 годы)

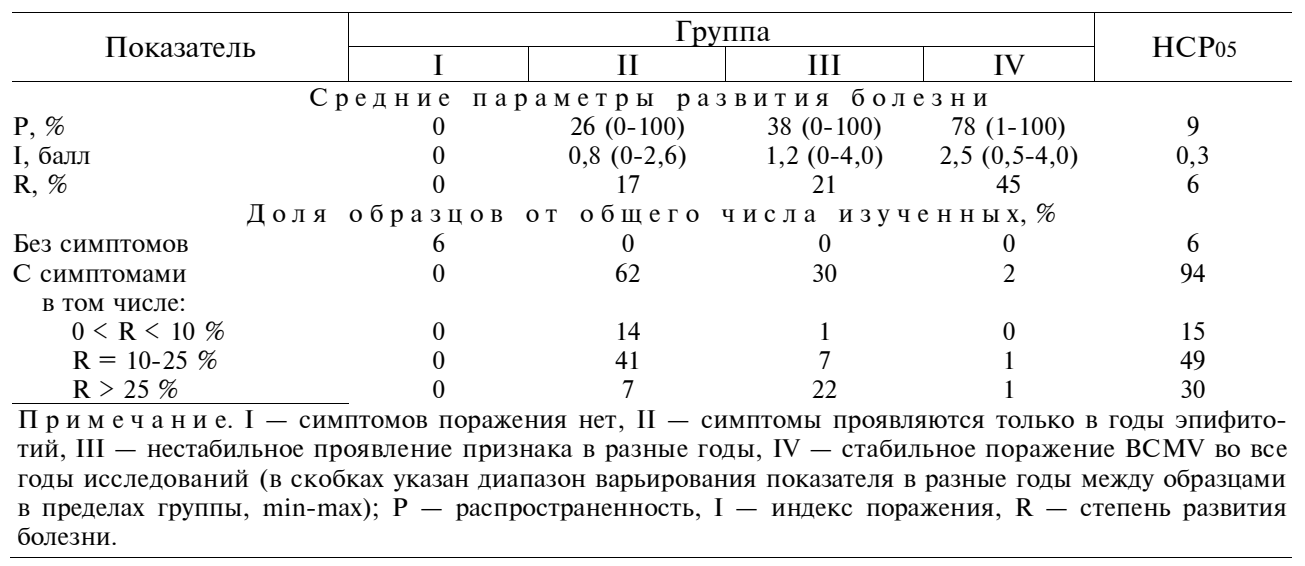

Поражение BCMV образцов самой многочисленной II группы регистрировали только во время эпифитотии болезни в 2016 и 2019 годах: в оба года вирусом поражались $30 \%$ образцов от общего числа изученных, $61 \%$ только в условиях 2016 года, $9 \%$ - только в 2019 году. В III группу вошли образцы, у которых наблюдали нестабильное проявление признака устойчивости: симптомы болезни на растениях отмечали в разные годы, в том числе с низкой интенсивностью инфекционного фона (2017-2018 годы).

Сравнение интенсивности развития BCMV в II и III группах показало, что по средним значениям за четыре года распространенность и индекс поражения растений в III группе были достоверно (соответственно $\chi^{2}=3,8$ при $\mathrm{p}=0,05$ и $\chi^{2}=6,6$ при $\mathrm{p}=0,01$ ) выше за счет большей доли образцов с R > 25 \% (см. табл. 2). Однако сравнение средних показателей за 2016 и 2019 годы выявило в пределах обеих групп образцы с высокой восприимчивостью ( $\mathrm{R}>75$ \%) к вирусу при эпифитотийной ситуации. Во II группе их доля составила около $1 \%$, в III $-4 \%$ от общего числа изу- 
ченных образцов. То есть объективно оценить степень устойчивости к BCMV каждого отдельного образца можно было только на фоне эпифитотий, причем в годы с различным сочетанием погодных условий, в то время как усредненный показатель (даже за несколько лет) не всегда позволял провести достоверный анализ изучаемого материала по указанному признаку. Это следует учитывать при отборе селекционно ценных образцов. В годы с низкой инфекционной нагрузкой можно проводить только негативный отбор, то есть выбраковку восприимчивых образцов.

Для результативного поиска источников устойчивости и ускорения селекционного процесса эффективно использование искусственного заражения растений в лабораторных условиях и методов молекулярного маркирования генов устойчивости к патогенам.

При ПЦР-анализе с маркером SW13, который тесно связан с доминантным геном I, мы получали ПЦР-продукт размером 690 п.н., как и описано ранее (50). Праймеры к маркеру SBD5 давали продукт амплификации размером 1300 п.н, что указывало на присутствие гена $b c-1^{2}(28,39)$. Праймеры к маркеру ROC11, сцепленному с геном $b c-3$, амплифицировали ДНК-фрагменты размером 300 п.н., тогда как в более ранних работах отмечали, что размер продукта должен достигать 420 п.н. $(31,40)$. Однако отклонения размера амплифицированного продукта ПЦР при работе с этим маркером обнаруживали и другие исследователи (52). Маркирование трех генов устойчивости $I, b c-1^{2}, b c-3$ позволило нам установить, что большинство из 30 изученных коллекционных образцов содержали ген $b c-3$ (табл. 3).

3. Результаты маркирования $R$-генов у образцов фасоли овощной (Phaseolus vulgaris L.) (коллекция ФГБНУ Федерального научного центра овощеводства), относящихся к разным группам стабильности и полевой устойчивости к вирусу обыкновенной мозаики фасоли (BCMV)

\begin{tabular}{|c|c|c|c|c|c|c|}
\hline \multirow[b]{2}{*}{$\begin{array}{l}\text { Группа ста- } \\
\text { бильности }\end{array}$} & \multirow[b]{2}{*}{ Образец } & \multirow[b]{2}{*}{$\begin{array}{l}\text { Степень развития } \\
\text { BCMV (R), \% }\end{array}$} & \multicolumn{3}{|c|}{ Маркер (ген) } & \multirow[b]{2}{*}{$\begin{array}{l}\text { Коэффициент } \\
\text { экстинкции }\end{array}$} \\
\hline & & & $\begin{array}{l}\mathrm{SW} 13 \\
(I)\end{array}$ & $\begin{array}{l}\text { SBD5 } \\
\left(b c-1^{2}\right)\end{array}$ & $\begin{array}{c}\mathrm{ROC} 11 \\
(b c-3)\end{array}$ & \\
\hline \multirow[t]{3}{*}{$\overline{\mathrm{I}}$} & Cade 128 & 0 & + & + & + & 0 \\
\hline & СП-232 & 0 & - & + & + & 0 \\
\hline & Хавская Универсальная & 0 & - & + & + & 0 \\
\hline \multirow[t]{12}{*}{ II } & Весточка & 2,5 & - & + & + & 0,115 \\
\hline & Рант & 2,9 & - & + & + & 0,118 \\
\hline & Кит-79 & 3,3 & + & + & + & H.T. \\
\hline & Верица & 7,7 & + & + & + & H.T. \\
\hline & КП-84 & 10,7 & + & + & + & H.T. \\
\hline & Фатима & 13,5 & + & + & - & 0,115 \\
\hline & Montdor & 14,0 & - & + & + & 0,100 \\
\hline & Пурпурная & 20,7 & + & + & + & H.T. \\
\hline & Holberg & 23,3 & + & - & - & 0,281 \\
\hline & Poroto Evestad & 30,0 & - & + & + & 0,280 \\
\hline & Arion & 31,7 & + & + & + & H.T. \\
\hline & Niagara 776 & 37,2 & + & - & + & 0,352 \\
\hline \multirow[t]{11}{*}{ III } & СП-164 & 4,0 & - & + & + & H.T. \\
\hline & СП-220 & 5,0 & + & + & + & H.T. \\
\hline & Золушка & 6,0 & - & + & + & 0,112 \\
\hline & МБ3 556 & 11,1 & - & - & - & 0,250 \\
\hline & Спаржевая & 11,7 & - & + & + & 0,114 \\
\hline & Секунда & 12,3 & - & + & + & 0,230 \\
\hline & Рубин & 16,2 & - & + & + & Н.T. \\
\hline & Плуто & 17,7 & + & + & + & 0,114 \\
\hline & Kentuky Wander & 19,3 & - & + & + & H.T \\
\hline & Dilano & 20,7 & + & + & + & H.T \\
\hline & Ранняя восковая & 25,0 & + & + & + & H.T \\
\hline \multirow[t]{3}{*}{ IV } & Лика & 7,8 & - & + & + & 0,114 \\
\hline & Кустовая & 17,1 & - & + & + & 0,240 \\
\hline & Грибовская 92 & 52,1 & - & - & - & 0,561 \\
\hline
\end{tabular}


При искусственном заражении 30 перспективных образцов с разными генотипами в лабораторных условиях на 14-е сут типичные симптомы поражения BCMV в виде мозаики и деформации листовой пластинки проявлялись только у растений, в геноме которых отсутствовали гены устойчивости $I$ и $b c-1^{2}$. У генотипов, содержащих эти гены, в зависимости от их сочетания была отмечена реакция по типу сверхчувствительности в виде точечных сухих некрозов в местах повреждения листовой пластинки, пожелтения и увядания зараженных листьев. Причем при наличии гена $I$ процесс увядания шел быстрее и уже на 10-е сут зараженные листья были практически сухими и легко отделялись от растения. Это подтверждалось значимыми коэффициентами корреляции между присутствием гена $I$ и балльной оценкой степени увядания листовой пластинки на момент учета ( $r$ от $+0,64$ до $+0,74$ в зависимости от сочетания генов). В то же время наличие в геноме $b c-1^{2}$ даже в отсутствие гена $I$ препятствовало появлению морщинистости ( $r$ от $-0,59$ до $-0,73)$, а также снижало степень проявления точечных некрозов вдоль жилок ( $r$ от $-0,35$ до -0,53).

При сопоставлении данных лабораторного опыта и полевой оценки устойчивости образцов прослеживалась отрицательная взаимосвязь между степенью поражения BCMV в поле и интенсивностью пожелтения листовой пластики сеянцев ( $r$ от $-0,52$ до $-0,85$ в зависимости от сочетания генов), а также положительная - с проявлением симптома морщинистости $(r$ от $+0,69$ до $+0,72)$. В то же время стабильно тесной взаимосвязи между наличием того или иного гена устойчивости и полевой устойчивостью генотипов в разные годы мы не выявили. В зависимости от напряженности инфекционного фона она изменялась от слабой до средней или отсутствовала. В некоторые годы отмечалась взаимосвязь между средним баллом поражения растений и присутствием генов $I$ ( $r$ от $-0,33$ до $-0,71)$ и $b c-1^{2}(r$ от $-0,35$ до $-0,57)$ в группе анализируемых образцов. Анализ соответствия по критерию $\chi^{2}$ между присутствием в геноме $R$-генов и средней степенью развития BCMV за все годы исследования выявил значимое влияние только гена $b c-1^{2}$ на степень полевой устойчивости образцов фасоли овощной в условиях Московской области (табл. 4).

Для всех полученных нами значений коэффициентов корреляции $r_{\text {критическое }}=0,36$ при $\left.\mathrm{p}=0,05\right)$.

4. Оценка соответствия между наличием генов устойчивости к вирусу обыкновенной мозаики фасоли (BCMV) и степенью поражения BCMV образцов фасоли овощной (Phaseolus vulgaris L.) (коллекция ФГБНУ Федерального научного центра овощеводства) на естественном инфекционном фоне (Московская обл., Одинцовский р-н, 2016-2019 годы)

\begin{tabular}{l|c|c|c|c|c}
\hline \multicolumn{1}{c|}{ Показатель } & $I$ & $b c-1^{2}$ & $b c-3$ & $I+b c-1^{2}$ & $I+b c-1^{2}+b c-3$ \\
\hline Число степеней свободы & 3 & 3 & 3 & 6 & 8 \\
Значение критерия $\chi^{2}$ факт. & 0,312 & 8,334 & 3,111 & 10,437 & 14,844 \\
Критическое значение $\chi^{2}$ при $\mathrm{p}<0,05$ & 7,815 & 7,815 & 7,815 & 12,592 & 15,507 \\
Наличие связи между факторами при & Нет & Да & Нет & Нет & Нет \\
уровне значимости & $\mathrm{p}=0,958$ & $\mathrm{p}=0,040$ & $\mathrm{p}=0,375$ & $\mathrm{p}=0,475$ & $\mathrm{p}=0,875$ \\
\hline
\end{tabular}

Тем не менее анализ распределения генотипов по степени развития болезни (R) в пределах отдельных выборок с разным сочетанием генов показал, что устойчивые образцы без признаков поражения BCMV на фоне эпифитотии 2019 года были выявлены только среди образцов с генотипами «+/+/+» и «-/+/+» (рис. 5, А, Б). Их доля составила соответственно 40 и $13 \%$, что подтверждает имеющиеся в литературе данные об усилении защитных функций растения при парной комбинации генов устойчивости $I$ и $b c-1^{2}$, хотя не во всех случаях такое сочетание гарантирует 
$100 \%$ эффективность. У половины образцов в этих выборках было зарегистрировано поражение растений вирусом в слабой степени $(\mathrm{R}<10 \%) ; 10 \%$ образцов с генотипом «+/+/+» и $33 \%$ с генотипом «-/+/+» проявили среднюю степень устойчивости $(\mathrm{R}=10-25 \%)$. Слабо обеспечило защиту растений в поле сочетание генов при отсутствии гена $b c-3$ («+/+/-» и «+/-/-»). Образцы с такими генотипами оказались средневосприимчивыми, а при отсутствии всех генов устойчивости (генотип «-/-/-») проявляли среднюю и высокую степень восприимчивости к BCMV.

Повсеместное использование генов неспецифической устойчивости I и $b c-3$ в зарубежных селекционных программах фасоли овощной привело к появлению новых штаммов BCMV, преодолевающих эти гены, и поражению устойчивых сортов близкородственным потивирусом BCMNV (9, 22). В 2018 году X. Feng с соавт. (22) показали, что использование рецессивных генов устойчивости $b c-1$ и $b c-2$ в отдельности или в комбинации друг с другом даже без доминантного гена $I$ эффективно в селекции на устойчивость ко многим патотипам BCMV. Эти гены не влияют на репликацию и перемещение вируса от клетки к клетке, но воздействуют на его системное распространение. Мы установили, что наличие той или иной комбинации генов не всегда обеспечивает устойчивость к вирусу в полевых условиях. На стабильность проявления признака устойчивости сорта в разные годы оказывают влияние климатические условия, которые во многом определяют физиологическое состояние растения, изменяя степень экспрессии $R$-генов, отвечающих за иммунный ответ и проявление симптомов при инфицировании патогеном. Высокую устойчивость к вирусу обыкновенной мозаики фасоли обеспечивало как сочетание доминантного гена $I$ с рецессивными $b c-1^{2}$ и $b c-3$, так и рецессивная устойчивость без доминантного гена. Практическую значимость для селекции на устойчивость к BCMV представляли устойчивые образцы I и II групп стабильности с генотипами «+/+/+» и «-/+/+» (см. рис. 5, В): Cade 128, СП-232, Верица, Кит-89, КП-84, Хавская универсальная, Весточка, Рант.

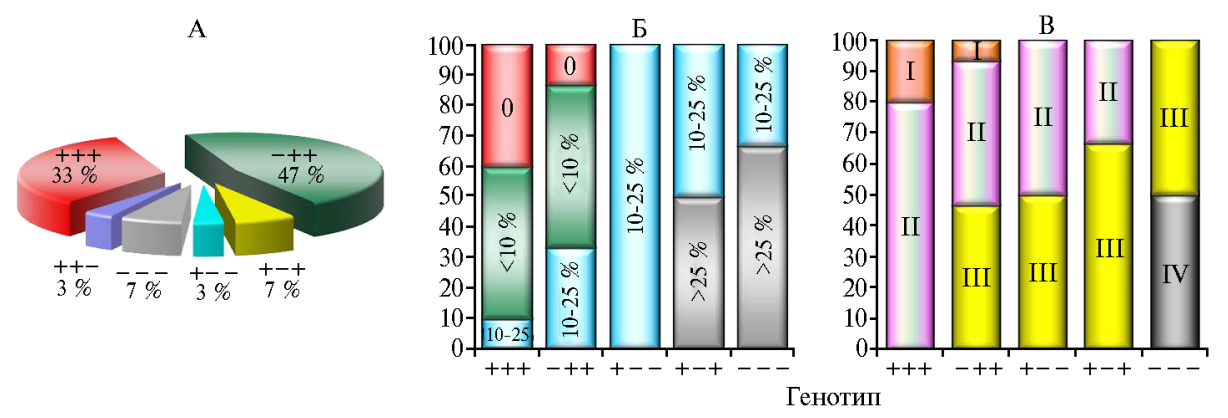

Рис. 5. Соотношение генотипов с разным сочетанием генов $I, b c-1^{2}, b c-3$ («+» - есть, «-»нет) в группе из 30 перспективных образцов фасоли овощной (Phaseolus vulgaris L.) (коллекция ФГБНУ Федерального научного центра овощеводства) (А) и их распределение по степени развития болезни (R) в 2019 году (Б) и по группам стабильности проявления устойчивости к вирусу обыкновенной мозаики фасоли (BCMV) в 2016-2019 годах в условиях открытого грунта (В): a - устойчивые $(\mathrm{R}=0)$, б - относительно устойчивые $(0<\mathrm{R} \leq 10 \%)$, в - слабовосприимчивые $(10<\mathrm{R} \leq 25 \%)$, г - восприимчивые ( $\mathrm{R}>25 \%)$; I - симптомов поражения нет, II - симптомы проявляются только в годы эпифитотий, III - нестабильное проявление признака в разные годы, IV - стабильное поражение BCMV во все годы исследований (Московская обл., Одинцовский р-н).

При подборе исходного материала для целевой селекции важно, чтобы выделенные образцы имели не только необходимые гены и высокую полевую устойчивость к патогену, но другие хозяйственно важные при- 
5. Характеристика селекционно ценных образцов фасоли овощной (Phaseolus vulgaris L.) (коллекция ФГБНУ Федерального научного центра овощеводства), выделенных по устойчивости к вирусу обыкновенной мозаики фасоли (BCMV) в условиях Московской области (20162019 годы)

\begin{tabular}{|c|c|c|c|c|c|c|c|c|c|c|c|c|c|}
\hline \multirow{2}{*}{$\begin{array}{l}\text { Название образца } \\
\text { (происхождение) }\end{array}$} & \multirow{2}{*}{ A } & \multirow{2}{*}{ Б } & \multirow{2}{*}{ B } & \multicolumn{6}{|c|}{ Бобы (фаза технической спелости), $M \pm \mathrm{SEM}$} & \multicolumn{4}{|c|}{ Семена (биологическая спелость), $M \pm \mathrm{SEM}$} \\
\hline & & & & $\Gamma$ & Д & $\mathrm{E}$ & Ж & 3 & И & $\mathrm{K}$ & Л & $\mathrm{M}$ & $\mathrm{H}$ \\
\hline \multicolumn{14}{|c|}{ У с то й ч и в ы е (I группа) } \\
\hline Изумрудная (Россия) & 0 & 3 & $10,5 \pm 0,8$ & T3 & 0 & $12,5 \pm 1,2$ & $0,9 \pm 0,1$ & $0,85 \pm 0,07$ & $90 \pm 4,1$ & б & $4,5 \pm 0,2$ & $250 \pm 14,5$ & $20 \pm 1,5$ \\
\hline Западная Сибирь (Россия) & 0 & 3 & $13,0 \pm 1,2$ & Ж & 0 & $12,5 \pm 1,1$ & $0,9 \pm 0,1$ & $0,82 \pm 0,08$ & $96 \pm 4,5$ & б & $4,3 \pm 0,2$ & $289 \pm 13,7$ & $19 \pm 1,2$ \\
\hline Забава (Россия) & 0 & 3 & $10,5 \pm 1,0$ & 3 & $0-1$ & $10,0 \pm 0,9$ & $0,8 \pm 0,0$ & $0,65 \pm 0,05$ & $82 \pm 3,7$ & б & $4,1 \pm 0,2$ & $279 \pm 15,2$ & $18 \pm 1,3$ \\
\hline Хавская универсальная (Россия) & 0 & 3 & $10,1 \pm 0,9$ & 3 & $0-1$ & $9,8 \pm 0,8$ & $1,0 \pm 0,1$ & $0,90 \pm 0,07$ & $82 \pm 3,4$ & б & $3,9 \pm 0,2$ & $235 \pm 13,4$ & $15 \pm 1,1$ \\
\hline Мулатка (Россия) & 0 & 2 & $14,5 \pm 1,3$ & $\Phi$ & $0-1$ & $13,5 \pm 1,2$ & $1,0 \pm 0,1$ & $0,85 \pm 0,06$ & $91 \pm 3,6$ & $\mathrm{cK}$ & $5,1 \pm 0,3$ & $302 \pm 17,5$ & $26 \pm 2,1$ \\
\hline Октава (Белоруссия) & 0 & 2 & $11,5 \pm 0,9$ & 3 & 0 & $13,8 \pm 1,2$ & $1,4 \pm 0,1$ & $1,05 \pm 0,09$ & $95 \pm 3,9$ & ч & $4,4 \pm 0,2$ & $204 \pm 12,3$ & $16 \pm 1,3$ \\
\hline Рябушка (Россия) & 0 & 3 & $10,5 \pm 0,8$ & Ж & $0-1$ & $14,2 \pm 1,3$ & $1,5 \pm 0,1$ & $0,70 \pm 0,05$ & $71 \pm 3,2$ & ч & $4,3 \pm 0,2$ & $250 \pm 15,4$ & $15 \pm 1,2$ \\
\hline Zit 551 RS (Нидерланды) & 0 & 3 & $11,5 \pm 0,8$ & 3 & $0-1$ & $9,5 \pm 0,7$ & $1,3 \pm 0,1$ & $0,80 \pm 0,04$ & $74 \pm 3,5$ & $\sigma$ & $3,9 \pm 0,2$ & $260 \pm 17,5$ & $14 \pm 1,1$ \\
\hline Cade 128 (Нидерланды) & 0 & 4 & $14,5 \pm 1,2$ & 3 & $0-1$ & $9,5 \pm 0,8$ & $0,9 \pm 0,1$ & $0,65 \pm 0,04$ & $80 \pm 4,1$ & б & $3,7 \pm 0,2$ & $271 \pm 12,7$ & $16 \pm 1,3$ \\
\hline Золотой нектар (Россия) $^{\circ}$ & 0 & 5 & $9,5 \pm 0,7$ & 3 & 0 & $17,4 \pm 1,5$ & $1,4 \pm 0,1$ & $0,85 \pm 0,05$ & $178 \pm 9,5$ & б & $5,5 \pm 0,3$ & $284 \pm 13,8$ & $34 \pm 2,7$ \\
\hline Фасоль местная овощнаяв (Россия) & 0 & 5 & $11,5 \pm 0,8$ & 3 & $0-1$ & $10,5 \pm 0,8$ & $0,8 \pm 0,1$ & $0,70 \pm 0,03$ & $160 \pm 8,7$ & 6 & $5,3 \pm 0,2$ & $207 \pm 9,7$ & $22 \pm 1,4$ \\
\hline \multicolumn{14}{|c|}{ О т н ос и те ль н о у с т о й ч и вы е (II, III группы) } \\
\hline Зинуля (Белоруссия) & 5,6 & 3 & $12,2 \pm 0,9$ & 3 & 0 & $10,5 \pm 0,8$ & $1,0 \pm 0,1$ & $0,93 \pm 0,08$ & $74 \pm 4,1$ & б & $3,8 \pm 0,2$ & $337 \pm 18,3$ & $15 \pm 0,9$ \\
\hline Bertires (Нидерланды) & 0,6 & 3 & $9,5 \pm 0,7$ & 3 & $0-1$ & $9,5 \pm 0,7$ & $0,8 \pm 0,1$ & $0,75 \pm 0,06$ & $88 \pm 4,7$ & $\sigma$ & $4,1 \pm 0,2$ & $285 \pm 15,9$ & $15 \pm 1,0$ \\
\hline Fanacnos (Польша) & 2,0 & 5 & $10,5 \pm 0,8$ & 3 & $0-1$ & $9,5 \pm 0,8$ & $1,0 \pm 0,1$ & $0,76 \pm 0,05$ & $74 \pm 4,5$ & б & $3,9 \pm 0,2$ & $275 \pm 14,3$ & $13 \pm 0,8$ \\
\hline Верица (Болгария) & 9,7 & 3 & $10,5 \pm 0,9$ & 3 & $0-1$ & $9,5 \pm 0,7$ & $1,1 \pm 0,1$ & $0,70 \pm 0,04$ & $75 \pm 4,3$ & $\sigma$ & $3,9 \pm 0,2$ & $319 \pm 16,4$ & $19 \pm 1,1$ \\
\hline Purpiat (Польша) & 8,8 & 2 & $13,5 \pm 1,1$ & $\Phi$ & $0-1$ & $10,5 \pm 0,7$ & $1,3 \pm 0,1$ & $0,72 \pm 0,04$ & $92 \pm 5,1$ & бж & $3,9 \pm 0,2$ & $427 \pm 17,2$ & $18 \pm 1,0$ \\
\hline Кит-№ 79 (Китай) & 6,1 & 2 & $17,5 \pm 1,3$ & 3 & $0-1$ & $15,5 \pm 0,9$ & $1,3 \pm 0,1$ & $0,95 \pm 0,07$ & $115 \pm 6,7$ & ч & $4,9 \pm 0,2$ & $367 \pm 15,8$ & $29 \pm 2,2$ \\
\hline
\end{tabular}

І и м е ч а н и е. А - устойчивость к ВCMV (R, \%); Б - группы спелости (2 - скороспелые, 3 - раннеспелые, 4 - среднеранние, 5 - среднеспелые), В - высота прикрепления

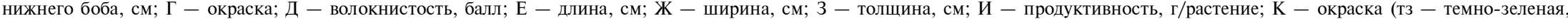

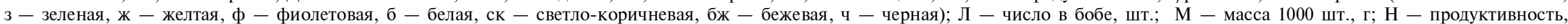
г/растение; в - вьющиеся растения. 
знаки. С этой точки зрения помимо устойчивых образцов из I группы стабильности интерес представляли относительно устойчивые коллекционные образцы ( $\mathrm{R}<10$ \% в годы эпифитотий) из II и III групп, которые были источниками ряда других признаков. Среди них наибольшую селекционную ценность имели 17 коллекционных образцов, характеристика которых представлена в таблице 5.

В рамках создания сортов для промышленного выращивания родительские формы подбирались по таким признакам, как раннеспелость, стабильная урожайность, сахарный боб, высокие технологические параметры (Изумрудная, Хавская универсальная, Октава, Мулатка); высокое прикрепление бобов на растении, сахарный боб, источники групповой устойчивости к болезням (Мулатка, Кит-№ 79, Purpiat, Cade 128); бобы прямые, caxapные, длинные (Золотой нектар, Мулатка, Рябушка); пригодность для заморозки и консервирования (Октава, Мулатка, Изумрудная), а также по некоторым другим признакам.

В личных подсобных хозяйствах спросом пользуются вьющиеся сорта фасоли овощной, которые позволяют получать свежие молодые бобы на протяжении продолжительного времени, или сорта детерминантного типа, но с растянутым периодом получения бобов. В качестве исходного материала для этого направления значительный интерес представляли образцы Золотой нектар, Кит-№ 79, Фасоль местная овощная, а также сорта селекции ФГБНУ ФНЦО - Ульяша и новый сорт фасоли овощной вьющегося типа Малюме, переданный на Государственное сортоиспытание в 2019 году. Следует отметить, что ряд наиболее востребованных сортов селекции ФГБНУ ФНЦО характеризуется высокой устойчивостью к бактериальным, грибным и вирусным болезням $(43,44)$, в том числе к BCMV. Это сорта Мариинка, Светлячок и Креолка, Рант и Пагода, которые по стабильности проявления устойчивости относились ко II и III группам. Обследование семеноводческих посевов этих сортов показало, что степень развития болезни в среднем за годы наблюдений не превышала $10 \%$. Обладая комплексом других хозяйственно ценных признаков (53), они также могут служить исходным материалом для дальнейшей селекции как источники устойчивости к ВCMV.

Таким образом, глобальное изменение климата привело к интенсификации распространения вируса обыкновенной мозаики фасоли (BCMV) на посевах фасоли овощной в северных регионах Российской Федерации. В условиях Московской области на распространенность вируса большее влияние оказывает количество выпавших осадков, а на интенсивность поражения растений - температура воздуха. Эпифитотийное развитие BCMV было зарегистрировано в 2015, 2016 и 2019 годах. При поиске источников устойчивости к этому заболеванию важно учитывать не только степень развития болезни, но и стабильность проявления признака устойчивости конкретного образца в течение ряда лет с различным сочетанием внешних факторов, обусловливающих напряженность естественного инфекционного фона. На основании критерия соответствия $\chi^{2}$ выявлено значимое влияние гена $b c-1^{2}$ на степень полевой устойчивости образцов фасоли овощной к BCMV. В климатических условиях Московской области наибольшую ценность в качестве источников генов устойчивости представляют образцы с генотипами $I / b c-1^{2} / b c-3$ и $-/ b c-1^{2} / b c-3$. По совокупности всех полученных результатов в качестве исходного материала для создания сортов фасоли овощной спаржевого типа с высокой устойчивостью к BCMV рекомендованы 17 наи- 


\section{ЛИТ ИРАТУРА}

1. De Ron A.M. Grain legumes. In: Handbook of plant breeding /A.M. De Ron (ed.). Pontevedra, 2015 (doi: 10.1007/978-1-4939-2797-5).

2. Broughton W.J., Hernández G., Blair M., Beebe S., Gepts P., Vanderleyden J. Beans (Phaseolus spp.) - model food legumes. Plant and Soil, 2003, 252: 55-128 (doi: 10.1023/A:1024146710611).

3. FAOSTAT - Food and Agriculture Organization. Режим доступа: http://faostat.fao.org. Без даты.

4. Вишнякова М.А., Булынцев С.В., Бурляева М.О., Буравцева Т.В., Егорова Г.П., Семенова Е.В., Сеферова И.В. Исходный материал для селекции овощных бобовых культур в коллекции ВИР. Овощи России, 2013, 1(18): 16-25 (doi: 10.18619/2072-9146-2013-1-16-25).

5. Verhoeven Th.J., Roenhorst J.W., Lesemann D.E., Segundo E., Velasco L., Ruiz L., Janssen D., Cuadrado I.M. Southern bean mosaic virus the causal agent of a new disease of Phaseolus vulgaris beans in Spain. European Journal of Plant Pathology, 2003, 109: 935-941 (doi: 10.1023/B:ЕJPР.0000003673.10046.2f).

6. Гнутова Р.В. Вирусные инфекции овощных бобовых культур и сои на Дальнем Востоке. Защита и карантин растений, 2013, 1: 14-17.

7. Reddick D., Stewart V.B. Transmission of the virus of bean mosaic in seed and observations on thermal death point of seed and virus. Phytopathology, 1919, 9: 445-450.

8. Flores-Estévez N., Acosta-Gallegos J.A., Silva-Rosales L. Bean common mosaic virus and Bean common mosaic necrosis virus in Mexico. Plant Disease, 2003, 87: 21-25 (doi: 10.1094/PDIS.2003.87.1.21).

9. Singh S.P., Schwartz H.F. Breeding common bean for resistance to diseases: a review. Crop Science, 2010, 50(6): 2199-2223 (doi: 10.2135/cropsci2009.03.0163).

10. Zhou G.-C., Wu X.-Y., Zhang Y.-M., Wu P., Wu X.-Z., Liu L.-W., Wang Q., Hang Y.-Y., Yang J.-Y., Shao Z.-Q., Wang B., Chen J.-Q. Genomic survey of thirty soybean-infecting bean common mosaic virus (BCMV) isolates from China pointed BCMV as a potential threat to soybean production. Virus Research, 2014, 191: 125-133 (doi: 10.1016/j.virusres.2014.07.029).

11. Biddle A.J. Peas and beans. Crop production science in horticulture /R. Russel, A. Lainsbury (eds.). Boston, 2017.

12. Verma P., Gupta U.P. Immunological detection of bean common mosaic virus in French bean (Phaseolus vulgaris L.) leaves. Indian J. Microbiol., 2010, 50: 263-275 (doi: 10.1007/s12088-010-0019-8).

13. Worrall E.A., Wamonje F.O., Mukeshimana G., Harvey J.J.W., Carr J.P., Mitter N. Bean common mosaic virus and Bean common mosaic necrosis virus: relationships, biology and prospects for control. In: Advances in virus research. V. 93 /M. Kielian, K. Maramorosch, T.C. Mettenleiter (eds.). Academic Press, NY, 2015: 1-46 (doi: 10.1016/bs.aivir.2015.04.002).

14. Поливанова Т.А., Крылов А.В. Вирусы, идентифицированные на бобовых культурах в Приморье. В кн.: Взаимоотношения вирусов с клетками растения-хозяина. Владивосток, 1985: 87-93.

15. Толкач В.Ф., Гнутова Р.В. Сравнительная биологическая характеристика вируса обыкновенной мозаики фасоли, выявленного на юге Дальнего Востока России и КНР. Доклады РАCXH, 1998, 5: 18-19.

16. Schippers B. Transmission of bean common mosaic virus by seed of Phaseolus vulgaris L. cv. Beka. Acta Botanica Neerlandica, 1963, 12(4): 433-497 (doi: 10.1111/j.1438-8677.1963.tb00130.x).

17. Drijfhout E. Genetic interaction between Phaseolus vulgaris L. and bean common mosaic virus with implications for strain identification and breeding for resistance. Wageningen, 1978.

18. Гнутова Р.В., Золотарёва Е.В. Болезни овощных культур и картофеля на Дальнем Востоке России. Владивосток, 2011.

19. Чекалин Н.М. Генетические основы селекции зернобобовых культур на устойчивость к патогенам. Полтава, 2003.

20. Diagnosis of plant virus diseases /R.E.F. Matthews (ed.). CRC Press, NY, 2018 (doi: 10.1201/9781351071352).

21. Larsen R.C., Miklas P.N., Druffel K.L., Wyatt S.D. NL-3 strain is a stable and naturally occurring interspecific recombinant derived from Bean common mosaic necrosis virus and Bean common mosaic virus. Phytopathology, 2005, 95(9): 1037-1042 (doi: 10.1094/phyto-95-1037).

22. Feng X., Orellana G.E., Myers J.R., Karasev A.V. Recessive resistance to bean common mosaic virus conferred by the $b c-1$ and $b c-2$ genes in common bean (Phaseolus vulgaris) affects longdistance movement of the virus. Phytopathology, 2018, 108(8): 1011-1018 (doi: 10.1094/phyto01-18-0021-R). 
23. Feng X., Guzmán P., Myers J.R., Karasev A.V. Resistance to bean common mosaic necrosis virus conferred by the $b c-1$ gene affects systemic spread of the virus in common bean. Phytopathology, 2017, 107(7): 893-900 (doi: 10.1094/phyto-01-17-0013-R).

24. Flasinski S., Gunasinghe U.B., Gonzales R.A., Cassidy B.G. The cDNA seqence and infectious transcripts of peanut stripe virus. Gene, 1996, 171(2): 299-308 (doi: 10.1016/0378-1119(96)00010-8).

25. Li Y., Cao Y., Fan Z., Wan P. Identification of a naturally ocurring Been common mosaic virus recombinant isolate infecting azuki bean. Journal of Plant Pathology, 2016, 98: 129-133 (doi: 10.4454/JPP.V98I1.071).

26. Kelly J.D. A review of varietal response to bean common mosaic potyvirus in Phaseolus vulgaris. Plant Varieties \& Seeds, 1997, 10(1): 1-6.

27. Li Y.Q., Liu Z.P., Yang Y.S., Zhao B., Fan Z.F, Wan P. First report of bean common mosaic virus infecting azuki bean (Vigna angularis) in China. Plant Disease, 2014, 98: 1017 (doi: 10.1094/PDIS-01-14-0064-PDN).

28. Kelly J.D., Afanador L., Haley S.D. Pyramiding genes for resistance to bean common mosaic virus. Euphytica, 1995, 82: 207-212 (doi: 10.1007/BF00029562).

29. Naderpour M., Johansen I. E. Visualization of resistance responses in Phaseolus vulgaris using reporter tagged clones of Bean common mosaic virus. Virus Research, 2011, 159(1): 1-8 (doi: 10.1016/j.virusres.2011.04.004).

30. Naderpour M., Lund, O. S., and Johansen, I. E. Sequence analysis of expressed cDNA of Bean common mosaic virus RU1 isolate. Iran J. Virus, 2009, 3: 41-43.

31. Mukeshimana G., Pañeda A., Rodríguez-Suárez C., Ferreira J.J., Giraldez R., Kelly J.D. Markers linked to the bc-3 gene conditioning resistance to bean common mosaic potyviruses in common bean. Euphytica, 2005, 144: 291-299 (doi: 10.1007/s10681-005-7397-8).

32. Haley S.D., Afanador L., Kelly J.D. Identification and application of a random amplified polymorphic DNA marker for the $I$ gene (potyvirus resistance) in common bean. Phytopathogy, 1994, 84: 157-160 (doi: 10.1094/phyto-84-157).

33. Melotto M., Afanador L. Kelly J.D. Development of a SCAR marker linked to the $I$ gene in common bean. Genome, 1996, 39(6): 1216-1219 (doi: 10.1139/g96-155).

34. Miklas P.N., Larsen R.C., Riley R., Kelly J.D. Potential marker-assisted selection for $b c-1^{2}$ resistance to bean common mosaic potyvirus in common bean. Euphytica, 2000, 116(3): 211219 (doi: 10.1023/a:1004006514814).

35. Vandemark G.J., Miklas P.N. Genotyping common bean for the potyvirus resistance alleles $I$ and $b c-1^{2}$ with a multiplex real-time polymerase chain reaction assay. Phytopathology, 2005, 95: 499-505 (doi: 10.1094/phyto-95-0499).

36. Strausbaugh C.A., Myers J.R., Forster R.L., McClean P.E. $B c-1$ and $b c-u-$ two loci controlling bean common mosaic virus resistance in common bean are linked. Journal of the American Society for Horticultural Science, 1999, 124(6): 644-648 (doi: 10.21273/JASHS.124.6.644).

37. Miklas P.N., Hang A.N., Kelly J.D., Strausbaugh C.A., Forster R.L. Registration of three kidney bean germplasm lines resistant to bean common mosaic and necrosis potyviruses: USLK-2 light red kidney, USDK-4 dark red kidney, and USWK-6 white kidney. Crop Science, 2002, 42(2): 674-675 (doi: 10.2135/cropsci2002.6740).

38. Pastor-Corrales M.A., Kelly J.D., Steadman J.R., Lindgren D.T., Stavely J.R., Coyne D.P. Registration of six great Northern bean germplasm lines with enhanced resistance to rust and bean common mosaic and necrosis potyviruses. Plant Registrations, 2007, 1(1): 77-79 (doi: 10.3198/jpr2005.12.0517crg).

39. Sharma P.N., Pathania A, Kapil R., Sharma P., Sharma O.P., Patial M., Kapoor V. Resistance to bean common mosaic potyvirus strains and its inheritance in some Indian land races of common bean. Euphytica, 2008, 164: 173-180 (doi: 10.1007/s10681-008-9689-2).

40. Johnson W.C., Guzmán P., Mandala D., Mkandawire A.B.C., Temple S., Gilbertson R.L., Gepts P. Molecular tagging of the $b c-3$ gene for introgression into Andean common bean. Crop Science, 1997, 37(1): 248-254 (doi: 10.2135/cropsci1997.0011183X003700010044x).

41. Енгалычева И.А., Козарь Е.Г., Антошкин А.А., Пронина Е.П., Волков Ю.Г., Какарека Н.Н., Щелканов М.Ю., Гапека А.В. Перспективы селекции овощных культур семейства Fabaceae на устойчивость к вирусу желтой мозаики фасоли (Potyvirus, Potyviridae) в условиях Московской области. Овощи России, 2018, 6(44): 77-83 (doi: 10.18619/2072-9146-2018-6-77-83).

42. Ракина М.С. Биоресурсный потенциал зернобобовых культур из коллекции мирового генофонда всероссийского научно-исследовательского института растениеводства им. Н.И. Вавилова. Автореф. канд. дис. Новосибирск, 2011.

43. Лазарева Е.К. Морфобиологические и биохимические особенности сортообразиов фасоли обыкновенной (Phaseolus vulgaris L.) в условиях Орловской области. Автореф. канд. дис. Рамонь, 2006.

44. Плетнева М.М. Оценка образцов фасоли обыкновенной по хозяйственно-ценным признакам и качеству зерна для селекции в южной лесостепи Западной Сибири. Автореф. канд. дис. Омск, 2019.

45. Енгалычева И.А., Плешакова Т.И., Гапека А.В., Тимина Л.Т. Мониторинг особо опас- 
ных вирусных заболеваний культур семейства Бобовые в условиях Московской области. Мат. Межд. науч.-практ. конф. молодых ученых и специалистов «Повышение эффективности сельскохозяйственной науки в современных условиях материалы международной научно-практической конференции молодых ученых и специалистов». Краснодар, 2015, 41-44.

46. Mills L.J., Silbernagel M.J. A rapid screening technique to combine resistance to halo blight and bean common mosaic virus in Phaseolus vulgaris L. Euphytica, 1991, 58: 201-208 (doi: 10.1007/BF00025251).

47. Методические указания и рекомендации по селекции и семеноводству овощных бобовых и капустных культур /Под ред. В.Ф. Пивоварова, Н.С. Цыганка. М., 2001.

48. Методические указания по селекции и первичному семеноводству овощных бобовых. М., 1985.

49. Hegay S., Ortiz R., Garkava-Gustavsson L., Hovmalm H.P, Geleta M. Marker-aided breeding for resistance to bean common mosaic virus in Kyrgyz bean cultivars. Euphytica, 2013, 193(1): 67-78 (doi: 10.1007/s10681-013-0928-9).

50. Vallejos C.E., Astua-Monge G., Jones V., Plyler T.R., Sakiyama N.S., Mackenzie S.A. Genetic and molecular characterization of the I locus of Phaseolus vulgaris. Genetics, 2006, 172(2): 1229-1242 (doi: 10.1534/genetics. 105.050815).

51. Доспехов Б.А. Методика полевого опыта. М., 1975.

52. Pasev G., Kostova D., Sofkova S. Identification of genes for resistance to bean common mosaic virus and bean common mosaic necrosis virus in snap bean (Phaseolus vulgaris L.) breeding lines using conventional and molecular methods. Journal of Phytopathology, 2014, 162(1): 19-25 (doi: 10.1111/jph.12149).

53. Антошкин А.А., Деговцов В.Е., Пронина Е.П., Антошкина М.С. Спаржевые сорта фасоли овощной селекции ВНИИССОК и их пригодность для переработки. Зернобобовые $u$ крупяные культуры, 2014, 4(12): 86-89.

ФГБНУ Федеральный научный центр овощеводства, 143080 Россия, Московская обл., Одинцовский р-н,

Поступила в редакцию пос. ВНИИССОК, ул. Селекционная, 14,

e-mail: engirina1980@mail.ru $₫$, kozar_eg@mail.ru, arthurdom@inbox.ru,

aa_antoshkin@mail.ru, pivovarov@vniissok.ru, usasa74@rambler.ru,

goroh@vniissok.ru

Sel'skokhozyaistvennaya biologiya [Agricultural Biology], 2020, V. 55, № 5, pp. 901-919

\title{
DEVELOPMENT PECULIARITIES OF BEAN COMMON MOSAIC VIRUS (Potyvirus, Potyviridae) IN MOSCOW REGION AND INITIAL MATERIAL FOR RESISTANCE BREEDING
}

\author{
I.A. Engalycheva $\bowtie$, E.G. Kozar, A.S. Domblides, A.A. Antoshkin, V.F. Pivovarov, \\ A.A. Ushakov, V.A. Ushakov
}

Federal Research Center for Vegetable Growing, 14, ul. Selektsionnaya, pos. VNIISSOK, Odintsovskii Region, Moscow Province, 143080 Russia, e-mail engirina1980@mail.ru (corresponding author $₫$ ), kozar_eg@mail.ru, arthurdom@inbox.ru, aa_antoshkin@mail.ru, pivovarov@vniissok.ru, usasa74@rambler.ru, goroh@vniissok.ru ORCID:

Engalycheva I.A. orcid.org/0000-0003-4843-111x Kozar E.G. orcid.org/0000-0002-1319-5631 Domblides A.S. orcid.org/0000-0002-5617-9498 Antoshkin A.A. orcid.org/0000-0002-3534-2727

The authors declare no conflict of interests

Received June 15, 2020
Pivovarov V.F. orcid.org/0000-0001-9522-8072

Ushakov A.A. orcid.org/0000-0002-1319-5631

Ushakov V.A. orcid.org/0000-0001-8901-1424

doi: 10.15389/agrobiology.2020.5.901eng

\section{Abstract}

Recent years have seen a significant expansion in the distribution area of bean common (Phaseolus vulgaris L.) mosaic virus (BCMV) that has become an economically significant disease agent for the non-chernozem part of Russia. As early as 2014, the epiphytotics were observed in the Moscow region, but no BCMV resistance screening in both Russia and foreign bean accessions has been performed yet in these agroclimatic conditions. Thus, the presented study is the first one that has described the features of BCMV development in the Moscow region and defines climatic factors affecting the disease progression. An assortment of bean accessions has been estimated on a level of resistance to BCMV using different techniques including molecular markers. The goal of the study was to find an initial breeding material as a source for development of new competitive BCMV-resistant local yardlong bean cultivars. The research was carried 
out in the Moscow Province in 2014-2019. The research methods included visual and serological diagnosis and phytopathological monitoring of disease progression of artificial and natural infection. Field testing of disease resistance in accessions of various genetic and geographical origins over time was performed using a four-point scale; the accessions were ranked into resistance groups based on the degree of the disease with regard to the stability of expression of the characteristic in various years. DNA analysis of the main resistance genes, i.e. dominant gene $I$ and recessive genes $b c-12$ and $b c-3$, was performed using the respective markers SW13, SBD5, and ROC11, following the developed procedures. The result of the study was the identification of the biological features of the BCMV isolate from the Moscow region affecting Phaseolus vulgaris L. and Pisum sativum L. from the Fabaceae family in biotest. The expression of symptoms and intensity of the disease in indicator plants in a greenhouse and bean accessions in field trials significantly depended on temperature, and the spread of the virus - on the accumulated precipitation. In general, reduced precipitation in combination with elevated temperatures served as a deterrent preventing the pathogen from further spreading in the climatic conditions of the Moscow region. At the same time, this combination facilitated viral infection manifestations on the plant leaf apparatus, especially during the vegetation period. Out of 207 accessions studied, only $6 \%$ demonstrated a persistently high BCMV resistance in the context of epiphytotics. Screening of 30 accessions with different resistance levels showed that recessive genes $b c-12$ and $b c-3$ were present in the majority of the accessions and dominant gene $I$ only in half of all accessions. Most accessions had genotypes $I / b c-12 / b c-3(33 \%)$ and $b c-12 / b c-3$ (47\%), among which only $1 / 3$ demonstrated a persistently high virus resistance. The plants lacking the genes $I$ and $b c-12$ were severely damaged by the virus. The chi-square test $\left(\chi^{2}\right)$ revealed a more significant effect of gene $b c-12$ on the field resistance of common bean accessions to BCMV. Based on the results obtained, as an initial breeding material for developing yardlong bean cultivars with high BCMV resistance we recommend 17 most promising accessions of different origin, including 5 cultivars (Khavskaya Universalnaya, Rant, Zolushka, Marlinka, Svetlyachok) and two perspective hybrids (SP-232, KP84) selected at Federal Research Center for Vegetable Growing that are distinguished by several agronomic characters.

Keywords: Phaseolus vulgaris L., green bean, bean common mosaic virus, BCMV, virus resistance, resistance genes, sustainable resistance, DNA-markers, initial material. 